Jurnal Bisnis dan Manajemen, Volume 19, No. 2, September 2018, p. 101-108

\title{
THE MARKETING OF HIGHER EDUCATION: MANAGING STUDENT LOYALTY BASED ON TUITION FEE POLICY AND SERVICE QUALITY
}

\author{
Yunia Wardi ${ }^{1}$, Abror ${ }^{2}$, Okki Trinanda ${ }^{3}$ \\ ${ }^{123}$ Universitas Negeri Padang, Indonesia
}

\begin{abstract}
This research investigates the influence of Single Tuition Fee System (STS) and Service Quality on Universitas Negeri Padang's students' intention to transfer to other universities. It also examines the correlation between Service Quality and STS in influencing the students' intention to switch. The population of this study was 8,314 non-Bidikmisi Scholarship students from the class of 2013 and 2014. The sample size was determined by using Slovin formula, and it employed 400 students as the samples by using accidental sampling method. The data have been collected by using survey method with the questionnaires as the data collection method. This study analyzes the data by using path and correlation analysis. Before the main analysis, this study has conducted some preliminary analysis such as normality and multicollinearity test. The result of the research shows that: (1) the STS has a significant positive effect on students' intention to transfer to other universities, (2) Service quality has a significant negative effect on students' intention to transfer to other universities, and (3) There is a significant correlation between STS and service quality in influencing students' intention to transfer to other universities. Some limitations and future study have been addressed.
\end{abstract}

Keywords: Single Tuition Fee System (STS), Service Quality, Students' Intention to Transfer

\section{PEMASARAN DI PERGURUAN TINGGI: MANAJEMEN LOYALITAS MAHASISWA TERHADAP KEBIJAKAN BIAYA KULIAH DAN KUALITAS PELAYANAN}

\begin{abstract}
ABSTRAK
Penelitian ini bertujuan untuk menganalisis pengaruh Uang Kuliah Tunggal dan Kualitas Pelayanan pada Universitas Negeri Padang terhadap keinginan mahasiswa untuk pindah ke Perguruan Tinggi lain, dan menganalisis korelasi antara Uang Kuliah Tunggal dan Kualitas Pelayanan pada Universitas Negeri. Populasi dari penelitian ini adalah 8.314 mahasiswa UNP non-Bidikmisi angkatan 2013 dan 2014. Ukuran sampel ditetapkan dengan menggunakan rumus Slovin sebesar 400 orang mahasiswa dengan menggunakan teknik accidental sampling. Data dalam penelitian ini dikumpulkan melalui survey dengan menggunakan kuisioner. Data yang diperoleh kemudian dianalisis dengan menggunakan path analysis dan correlation analysis. Sebelum analisis utama, penelitian ini juga sudah melakukan tes persyaratan analisis seperti tes normalitas dan multikolinearitas. Penelitian ini menemukan bahwa: (1) Uang Kuliah Tunggal memiliki pengaruh positif signifikan terhadap keinginan mahasiswa untuk pindah ke Perguruan Tinggi lain, (2) Kualitas Pelayanan memiliki pengaruh negatif signifikan terhadap keinginan mahasiswa untuk pindah ke Perguruan Tinggi lain, dan (3) terdapat korelasi antara Uang Kuliah Tunggal dan Kualitas Pelayanan dalam mempengaruhi keinginan mahasiswa untuk pindah ke Perguruan Tinggi lain. Studi ini jug mendiskusikan beberapa kelemahan dan peluang riset dimasa datang.
\end{abstract}

Kata-kata Kunci: Uang Kuliah Tunggal (UKT), Kualitas Pelayanan, minat mahasiswa pindah universitas

Korespondensi: Prof. Dr. Yunia Wardi, Drs., M.Si. Universitas Negeri Padang. Jln. Prof. Hamka Air Tawar Padang Sumatera Barat 25132. Email: yuniawardi@gmail.com.

Submitted: July 2018, Accepted: August 2018, Published: September 2018

ISSN: 1412 - 3681 (printed), ISSN: 2442 - 4617 (online), Website: http://journal.feb.unpad.ac.id/index.php/jbm 


\section{INTRODUCTION}

Based on the 2015 Academic Regulation of Universitas Negeri Padang (UNP), a student is allowed to move from UNP to other universities. It is common if students want to move to other universities due to a particular reason. However, if they move in relatively large numbers, then, this phenomenon becomes a problem for the UNP.

UNP certainly has some students who want to move to other universities. They have several possible reasons to move, such as the higher tuition fees than other universities', the perceived service quality of the university compared to their expectation, and the higher tuition fees compared to their senior colleagues (Hapsari, Clemes, \& Dean, 2017; Miranda, Tavares, \& Queiró, 2017; Johnston, 1995).

Furthermore, since the last few years, UNP had applied a Single Tuition System (STS), STS is a tuition fees' system where the student will pay with the same amount of money for each tuition fees level in every semester. The amount of payment on STS is varied among students. The UNP has categorized the tuition fees based on the economic condition of the parents of students. Accordingly, a student from a high level of income will pay more than a student from a lower income. Moreover, the university has also considered the number of dependents in that family. The higher the number of dependents, the lower tuition fees is.

Although the implementation of this STS has been arranged in such a way, the reality shows that most of the students perceived that STS is more expensive than the previous tuition fees system. Some students feel that STS is not fair for them, because they perceived different service quality from the university. Also, it is found a mistake where the student who comes from a lower family income may get a higher tuition fee.

Accordingly, if the UNP ignores these phenomena, the students' intention to transfer to other universities would be increased. Moreover, when the improvement of service quality does not follow the higher STS, they will be dissatisfied and try to find a better place for study (Meesala \& Paul, 2018; Han \& Hyun, 2017; Hapsari et al., 2017; Mao \& Oppewal, 2010).

Based on the above phenomenon, this study aims to examine (1) the influence of STS and Service Quality on the students' intention to transfer to other universities, and (2) to investigate the correlation between STS and Service Quality in influencing students' intention to transfer to other universities

\section{LITERATURE REVIEW}

The students' intention to transfer is related to loyalty concept (Han \& Hyun, 2018). It is an attitude where a student has a desire to move to another university. According to Kotler (2003), one way to retain customers is by creating switching barriers for the customers to switch to other product or service. Akwensivie (2014) in his research on food store consumers found that the standard of store service and poor of service 
delivery might become a key factor for customer switching behavior.

Switching barrier is an effort which is made by the company or organization to retain the customers such as the university's students (H.-C. $\mathrm{Wu} \& \mathrm{Ai}, 2015)$. The organization, such as the university, may use the service quality improvement based on customers' expectation, and the changing in pricing policy (e.g., tuition fees policy) as the ways to retain the students. Furthermore, Lovelock and Wirtz (2007) assert that to overcome the transfer of customers can be done by delivering high-quality services. By delivering the best service quality, it may lead to the customer retention.

According to some previous studies, service quality has some dimensions, including physical evidence (tangibles), reliability, responsiveness, assurance, and empathy (Mugion, Toni, Raharjo, Di Pietro, \& Sebathu, 2018; Miranda et al., 2017; Parasuraman, Zeithaml, \& Berry, 1985).

Tangibles are all physical evidence such as physical facilities, equipment and personnel appearance (Miranda et al., 2017; Parasuraman, Zeithaml, \& Berry, 1988). Reliability is the ability to deliver promptly, accurately and satisfactorily (Miranda et al., 2017). Responsiveness relates to the willingness to help customers and provide prompt service (Meesala \& Paul, 2018, p. 2). Assurance refers to knowledge and courtesy of employees and their ability to inspire trust and confidence (Miranda et al., 2017, p. 2). Empathy relates to caring, individualized attention the firm provides to its customers (Meesala \& Paul, 2018, p. 2). Moreover, Marcovic and Raspor (2010) in their research explain that reliability, empathy, staff competence, accessibility, and physical evidence are the best critical factors for explaining consumer expectations for service quality.

Furthermore, another way to create a switching barrier is by using pricing policy (Zhang, Li, Wang, \& Wang, 2016; Martin, Ponder, \& Lueg, 2009). A few years ago, UNP made a pricing policy which is known as the Single Tuition System (STS). STS is the tuition fees policy where the students will pay the tuition fees in a fixed amount of money for each semester. In addition, Roos (1999) describes the determinants of moving consumers, among others, because of the price. Mazursky, Labarbera, and Aiello (1987) in their research found that most of the consumers are price consideration, coupon redemption, and they have a tendency to try a new brand.

Also, Sahay and Sharma (2010) explain that the significant change in the price will increase the consumers' desire to move. Moreover, Makwana, Sharma, and Arora ( 2014) argue that value-added services and pricing strategies are two critical factors that influence consumer behavior on the brand. Also, the price will affect the consumers in considering the quality of service (Iacobucci, Ostrom, \& Grayson, 1995).

Some previous studies argue that pricing policy, such as STS has a direct impact on customer loyalty (El-Adly, 2018; Wang, Hu, \& 
Liu, 2017; Martin et al., 2009). For example, ElAdly (2018) and Wang et al. (2017) have asserted that perceived value on price has a significant impact on customer loyalty. While, one of the indicators of loyalty or disloyalty is an intention to switch. Accordingly, we propose a hypothesis that STS as the pricing policy has a significant impact on student intention to switch (H1).

Service quality is also an antecedent of customer loyalty (El-Adly, 2018; Wardi, Abror, \& Trinanda, 2018; Rinala, Yudana, \& Natajaya, 2013; Abror, Evanita, \& Hidayat, 2012). Abror et al. (2012) assert that service quality has a significant impact on customer loyalty. Moreover, Han and Hyun (2018) and Hapsari et al. (2017) also argue that better service quality will significantly lead to the customer loyalty. Intention to switch is an indicator of disloyalty. Hence, we argue that service quality will have a direct impact on the intention to switch. Hence, from the discussion above, we posit that service quality has a significant impact on customer loyalty $(\mathrm{H} 2)$.

Pricing policy has a relationship with service quality (Wang et al., 2017; Y. Wu \& Zhu, 2017; Liu \& Lee, 2016). Liu and Lee (2016) have argued that price and service quality are related. Accordingly, we believe that pricing strategy such as STS has a significant relationship with service quality. Therefore, we propose a hypothesis that service quality is significantly related to service quality (H3).

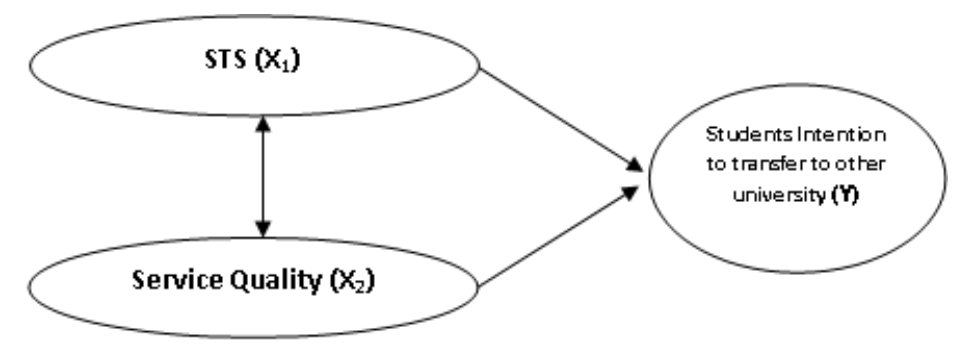

Figure 1 Conceptual Framework

\section{METHODS}

The population of this study was 8,314 nonBidikmisi Scholarship students from the class of 2013 and 2014. The sample size is determined using Slovin formula (Umar 2009: 49) with the percentage of sampling error 0.05 . Hence, we got 400 samples from seven faculties at UNP. We employed proportional sampling for each faculty. This study used the accidental sampling method as the data collection technique by using questionnaires. To analyze the data, we employed path analysis as the analysis technique by using SPSS as the data analysis software package (Hair, Black, Babin, \& Anderson, 2010). Before the primary analysis, we have done some preliminary analyses, such as normality, multicollinearity, heteroscedasticity and outlier test (Patrisia \& Dastgir, 2017; Abror \& Akamavi, 2015). In addition, we used a t-test for hypothesis testing (Wardi, Susanto, Abror, \& Abdullah, 2018). 


\section{RESULTS AND DISCUSSION}

The influence of a single tuition system (STS) on students' intention to transfer to other universities

Based on the path analysis, The $\mathrm{t}$ value of the relationship between STS and students' intention to transfer is 6.615 which is greater than 1.96 as the cutoff point for $\alpha 0.05$. The coefficient of STS in influencing students' intention to transfer to other universities is 0.316 . Hence, we found that STS has a significant impact on students' intention to transfer to another university (H1). This finding supports previous studies (El-Adly, 2018; Wang et al., 2017; Martin et al., 2009). For example, Hasan (2013) explains that customer switching behavior is associated with poor service quality and the reaction to high price.

Furthermore, Roos (1999) also explains that the determinants of moving consumers, among others, due to price. In addition, Mazursky et al. (1987) in his research found that price consideration is one factor which influences the switching behavior. Sahay and Sharma (2010) in their research also argue that the significant price changed will increase the switching intention of the customers. Accordingly, we argue that one significant determinant of student intention to move is the high STS. It means that when the STS is high, the student will have a higher intention to move.

\section{The influence of service quality on students' intention to transfer to other universities}

Based on the path analysis, we found the coefficient of service quality in influencing students' intention to transfer to other universities is -0.219 . The $t$ value of this relationship is $-4,588$, and it is higher than the $t$ table at $\alpha 0.05(-4,588>1.96)$. This means that the service quality has a significant and negative impact on the student intention to switch $(\mathrm{H} 2)$. This finding is similar to some prior studies (Meesala \& Paul, 2018; Miranda et al., 2017; Namin, 2017). For instance, Lovelock and Wirtz (2007) assert that to overcome the transfer of customers can be done by delivering good service quality. Moreover, the academic service quality also has a significant effect on student satisfaction (Rinala et al., 2013), hence, when the student satisfied, the willingness to switch will be low.

\section{The correlation between service quality and STS}

Based on the correlation analysis, we found that the correlation coefficient between STS and service quality is 0.160 with Pearson correlation significant value $0.001(<0.05)$. It means that there is a positive and significant correlation between the STS and the service quality (H3). This finding is in line with Zeithaml and Bitner (2003) and Sunyoto and Susanti (2015) who state that service quality is closely related to the customer's perceived price. $\mathrm{Y}$. Wu and $\mathrm{Zhu}$ (2017) also argue that the customer decision making to consume a service will consider the service price and service quality. In addition, Liu and Lee (2016) have also asserted that price and service quality is the key factors for word of mouth. Therefore, service quality and price have a close relationship. Hence, we have to concern both STS and service quality when we want to retain the student. 


\section{CONCLUSION}

In conclusion, this study has found that students' intention to move to other universities has two significant antecedents, including STS and service quality. STS has a positive and significant impact on students' intention to move, while, service quality has a significant and negative influence on student intention to move. Furthermore, there is a significant correlation between the independent variables. Furthermore, based on the above results and discussions, to create a high switching barrier for students, we suggest the UNP management to develop STS pricing policy which is affordable by the students, and some improvement in service quality should follow it. This study also has some limitations, such as (1) It is a cross-sectional study. Hence, it has a limitation in result generalization, (2) This study only focuses on two antecedents of switching behavior. For future research, we suggest to expand it to a longitudinal study and add some more variables such as student satisfaction and perceived value (El-Adly, 2018).

\section{REFERENCES}

Abror, \& Akamavi, R. K. (2015). Psychological safety and organisational performance in Indonesian companies: Preliminary findings Applied Psychology (pp. 8-38): World Scientific.

Abror, Evanita, S., \& Hidayat, K. (2012). Pengaruh Kepuasan Atas Kualitas Pelayanan dan Citra Merek terhadap Loyalitas Pelanggan Garuda Indonesia di Sumatera Barat. Jurnal Kajian Manajemen Bisnis, 1(1), 75-92.

Akwensivie, D. M. (2014). Switching Behaviour and Customer Relationship Management - The
Iceland Experience. British Journal of Marketing Studies, 2 (1), 89-100.

El-Adly, M. I. (2018). Modelling the relationship between hotel perceived value, customer satisfaction, and customer loyalty. Journal of Retailing and Consumer Services. Retreived from:

https://doi.org/10.1016/j.jretconser.2018.07.00 7

Hair, J. F., Black, W. C., Babin, B. J., \& Anderson, R. E. (2010). Multivariate data analysis. New Jersey: Prentice Hall.

Han, H., \& Hyun, S. S. (2017). Impact of hotelrestaurant image and quality of physicalenvironment, service, and food on satisfaction and intention. International Journal of Hospitality Management, 63, 82-92. Retreived from:

https://doi.org/10.1016/j.ijhm.2017.03.006

Han, H., \& Hyun, S. S. (2018). Role of motivations for luxury cruise traveling, satisfaction, and involvement in building traveler loyalty. International Journal of Hospitality Management, 70, 75-84. Retreived from: https://doi.org/10.1016/j.ijhm.2017.10.024

Hapsari, R., Clemes, M. D., \& Dean, D. (2017). The impact of service quality, customer engagement and selected marketing constructs on airline passenger loyalty. International Journal of Quality and Service Sciences, 9(1), 21-40. doi:10.1108/IJQSS-07-2016-0048

Hasan, A. (2013). Marketing dan Kasus-kasus Pilihan. Yogyakarta: CAPS.

Iacobucci, D., Ostrom, A., \& Grayson, K. (1995). Distinguishing Service Quality and Customer Satisfaction : The Voice of The Customer. Journal of Consumer Psychology, 4(3), 277303.

Johnston, R. (1995). The determinants of Service Quality : Satisfiers and Dissatisfiers. International Journal of Service Industry Management, 6(5), 55-71.

Kotler, P. (2003). Marketing Management An Asian Perspective. (Vol. Second Edition). New York: Prentice Hall.

Liu, C.-H. S., \& Lee, T. (2016). Service quality and price perception of service: Influence on wordof-mouth and revisit intention. Journal of Air Transport Management, 52, 42-54. doi: https://doi.org/10.1016/j.jairtraman.2015.12.00 7

Lovelock, C., \& Wirtz, J. (2007). Services Marketing : People, Technology, Strategy. USA: Pearson Prentice Hall. 
Makwana, K., Sharma, N., \& Arora, S. ( 2014). Factors Influencing Consumer Brand Switching Behavior in Telecommunication Industry : An Emperical Study. Prestige $e$ Journal of Management and Research, 1(1).

Mao, W., \& Oppewal, H. (2010). Did I choose the right university? How post-purchase information affects cognitive dissonance, satisfaction and perceived service quality. Australasian Marketing Journal (AMJ), 18(1), 28-35. Retreived from: https://doi.org/10.1016/j.ausmj.2009.10.002

Marcovic, S., \& Raspor, S. (2010). Measuring Perceived Service Quality Using Servqual : Case Study of the Croation Hotel Industry. Management, 5(3), 195-209.

Martin, W. C., Ponder, N., \& Lueg, J. E. (2009). Price fairness perceptions and customer loyalty in a retail context. Journal of Business Research, 62(6), 588-593. Retreived from: https://doi.org/10.1016/j.jbusres.2008.05.017

Mazursky, D., Labarbera, P., \& Aiello, A. (1987). When Consumers Switch Brand. Psychology and Marketing, 4(1), 17-30.

Meesala, A., \& Paul, J. (2018). Service quality, consumer satisfaction and loyalty in hospitals: Thinking for the future. Journal of Retailing and Consumer Services, 40, 261-269. Retreived from: https://doi.org/10.1016/j.jretconser.2016.10.01 1

Miranda, S., Tavares, P., \& Queiró, R. (2017). Perceived service quality and customer satisfaction: A fuzzy set QCA approach in the railway sector. Journal of Business Research. Retreived from: https://doi.org/10.1016/j.jbusres.2017.12.040

Mugion, R. G., Toni, M., Raharjo, H., Di Pietro, L., \& Sebathu, S. P. (2018). Does the service quality of urban public transport enhance sustainable mobility? Journal of Cleaner Production, 174, 1566-1587. Retreived from: https://doi.org/10.1016/j.jclepro.2017.11.052

Namin, A. (2017). Revisiting customers' perception of service quality in fast food restaurants. Journal of Retailing and Consumer Services, 34, 7081. Retreived from: https://doi.org/10.1016/j.jretconser.2016.09.00 8

Parasuraman, A., Zeithaml, V., A, \& Berry, L. L. (1985). A Conceptual Model of Service Quality and Its Implications for Future Research. Journal of Marketing, 49, 41-50.
Parasuraman, A., Zeithaml, V. A., \& Berry, L. L. (1988). SERVQUAL: A multiple- Item Scale for measuring consumer perceptions of service quality. Journal of Retailing, 64(1), 12-40.

Patrisia, D., \& Dastgir, S. (2017). Diversification and corporate social performance in manufacturing companies. Eurasian Business Review, 7(1), 121-139. doi: 10.1007/s40821-016-0052-6

Rinala, I. N., Yudana, I. M., \& Natajaya, I. N. (2013). Pengaruh Kualitas Pelayanan Akademik Terhadap Kepuasan dan Loyalitas Mahasiswa pada Sekolah Tinggi Pariwisata Nusa Dua Bali. e-Journal. Pascasarjana Universitas Pendidikan Ganesha Program Studi Administrasi Pendidikan, 4.

Roos, I. (1999). Switching Processes in Customer Relationship. Journal of Service Research, 2(1), 68-85.

Sahay, A., \& Sharma, N. (2010). Brand Relationships and Switching Behaviour for Highly Used in Young Consumers. VIKALVA, 35(1).

Sunyoto, D., \& Susanti, F. E. (2015). Manajemen Pemasaran Jasa Merencanakan, Mengelola, dan Membidik Pasar Jasa. Jakarta: CAPS (Center for Academic Publishing Service).

Wang, S., Hu, Q., \& Liu, W. (2017). Price and qualitybased competition and channel structure with consumer loyalty. European Journal of Operational Research, 262(2), 563-574. Retreived from: https://doi.org/10.1016/j.ejor.2017.03.052

Wardi, Y., Abror, A., \& Trinanda, O. (2018). Halal tourism: antecedent of tourist's satisfaction and word of mouth (WOM). Asia Pacific Journal of Tourism Research, 23(5), 463-472. doi: 10.1080/10941665.2018.1466816

Wardi, Y., Susanto, P., Abror, A., \& Abdullah, N. L. (2018). Impact of Entrepreneurial Proclivity on Firm Performance: The Role of Market and Technology Turbulence Pertanika J Soc. Sci. \& Hum, 26(S), 241-250.

Wu, H.-C., \& Ai, C.-H. (2015). A study of festival switching intentions, festival satisfaction, festival image, festival affective impacts, and festival quality. Tourism and Hospitality Research, 16(4), 359-384. doi: $10.1177 / 1467358415610375$

Wu, Y., \& Zhu, L. (2017). Joint quality and pricing decisions for service online group-buying strategy. Electronic Commerce Research and Applications, 25, 1-15. doi: https://doi.org/10.1016/j.elerap.2017.07.003 
Zeithaml, V., A , \& Bitner, M. J. (2003). Services Marketing Intergrating Customer Focus Across The Firm. New York McGraw Hill.

Zhang, R., Li, G., Wang, Z., \& Wang, H. (2016). Relationship value based on customer equity influences on online group-buying customer loyalty. Journal of Business Research, 69(9), 3820-3826. Retreived from: https://doi.org/10.1016/j.jbusres.2015.12.074 